\title{
O ensino em e da Libras: perfis profissionais para oferta da educação bilíngue no Brasil
}

\author{
Teaching Libras and in Libras: professional profiles for offering bilingual \\ education in Brazil \\ La enseñanza en y de la Libras: perfiles profesionales para la oferta de \\ educación bilingüe en Brasil
}

\section{Rubia Carla Donda da Silva}

Doutoranda na Universidade Estadual Paulista Júlio de Mesquita Filho, Marília, São Paulo, Brasil. rubidonda@hotmail.com

ORCID - https://orcid.org/0000-0002-2959-8486

\section{Sandra Eli Sartoreto Oliveira Martins}

Professora doutora na Universidade Estadual Paulista Júlio de Mesquita Filho, Marília, São Paulo, Brasil. sandra.sartoreto@gmail.com

ORCID - http://orcid.org/0000- 0002-4247-1447

Recebido em 31 de maio de 2019

Aprovado em 7 de agosto de 2019

Publicado em 22 de outubro de 2019

\section{RESUMO}

O presente artigo objetiva traçar o panorama da equipe de profissionais responsáveis pelo ensino em Libras e da Libras para a consecução da educação bilíngue atenta aos direitos linguísticos dos surdos, no Brasil. De caráter documental, o estudo envolveu a coleta dos Planos Nacional, Estaduais e Distrital de Educação, disponíveis no portal "PNE em Movimento". Na sequência, os documentos foram lidos na íntegra, de modo a selecionar excertos que caracterizassem o perfil dos profissionais responsáveis pelo atendimento educacional dos estudantes surdos e exibi-los em mapas respeitando a ocorrência e distribuição por estados. Assim, foi possível comparar as escolhas efetuadas nos contextos locais, explicitar tendências e exceções e ativar a interlocução com os enunciados contidos nos Planos de Educação investigados e demais dispositivos oficiais a eles associados. Por intermédio das análises, múltiplas composições do quadro funcional foram identificadas e diferentes denominações apontaram atributos profissionais que denotam concepções distintas de educação bilíngue, as quais conferem valor diferenciado à Libras e, por conseguinte, aos estudantes surdos, no processo educacional. Em ordem decrescente, os Planos investigados indicam a provisão de 
http://dx.doi.org/10.5902/1984686X38356

intérpretes de Libras, professores do Atendimento Educacional Especializado, professores bilíngues e professores e/ou instrutores de Libras, prioritariamente surdos, para atender às demandas de escolarização dos estudantes surdos. Tais constatações permitiram problematizar propostas que concebem a Libras como recurso para o ensino em português, e evidenciar disposições que têm a língua de sinais como língua constitutiva das pessoas surdas que integram o sistema de ensino brasileiro.

Palavras-chave: Libras; Educação bilíngue; Direitos linguísticos; Surdo.

\section{ABSTRACT}

This article aims to draw the panorama of the team of professionals responsible for teaching Libras (Brazilian Sign Language) and in Libras to achieve bilingual education attentive to the linguistic rights of deaf people in Brazil. With a documentary character, this study involved the collection of the National, State and District Education Plans, available on the "PNE em Movimento" webpage. Subsequently, the documents were read in full, in order to select excerpts that characterized the profile of the professionals responsible for the educational assistance of deaf students and display them on maps respecting the occurrence and distribution by states. Thus, it was possible to compare the choices made in the local contexts, explain trends and exceptions and activate the dialogue with the statements contained in the Education Plans investigated and other official devices associated with them. Through the analyzes, multiple compositions of the staff were identified, and different denominations pointed to professional attributes that denote different conceptions of bilingual education, which give differentiated value to Libras and, therefore, to deaf students in the educational process. In descending order, the plans investigated indicated the provision of Libras' interpreters, specialized educational services teachers, bilingual teachers, and primarily deaf teachers and/or instructors of Libras to meet the educational demands of deaf students. These findings allowed us to problematize proposals that conceive Libras as a resource for teaching in Portuguese, and to highlight provisions that have sign language as a constitutive language of deaf people in the Brazilian educational system.

Keywords: Libras; Bilingual education; Linguistic rights; Deaf.

\section{RESUMEN}

Este artículo tiene como objetivo dibujar un panorama del equipo de profesionales responsables de la enseñanza en Libras y de la Libras para lograr una educación bilingüe, preocupada con los derechos lingüísticos de las personas sordas en Brasil. Con perfil documental, el estudio envolvió la coleta de los Planes Nacional, Estatales y del Distrito de la educación, disponibles en el portal "PNE en movimiento". En secuencia, los documentos se leyeron en su totalidad, con la finalidad de seleccionar extractos que caracterizaran el perfil de los profesionales responsables de la asistencia educativa de los estudiantes sordos y mostrarlos en mapas, respetando la ocurrencia y distribución por estados. Así, fue posible comparar las elecciones realizadas en los contextos locales, explicar tendencias y excepciones, activar el diálogo con las declaraciones contenidas en los Planes de educación investigados y otros dispositivos oficiales asociados con ellos. A través de los análisis, se identificaron múltiples composiciones del personal y diferentes denominaciones señalaron atributos profesionales que denotan diferentes concepciones 
http://dx.doi.org/10.5902/1984686X38356

de la educación bilingüe, que otorgan un valor diferenciado a la Lengua Brasileña de Señas y, por lo tanto, a los estudiantes sordos en el proceso educativo. En orden decreciente, los Planes investigados indicaron la provisión de intérpretes de Libras, maestros del Servicio Educativo Especializado, maestros bilingües y maestros y/o instructores de Libras, de preferencia sordos, para atender a las demandas de escolarización de los estudiantes sordos. Estas constataciones permitieron problematizar propuestas que conciben la Lengua Brasileña de Señas como recurso para la enseñanza en portugués, y evidenciar disposiciones que tiene la lengua de señas como lengua constitutiva de las personas sordas que integran el sistema de enseñanza brasileña.

Palabras clave: Libras; Educación bilingüe; Derechos lingüísticos; Sordo.

\section{Introdução}

O anseio pela consolidação de uma política nacional de educação bilíngue que integre a Libras e a modalidade escrita da Língua Portuguesa como línguas de instrução, no desenvolvimento de todo o processo educativo (BRASIL, 2005), tem suas raízes firmadas nas reivindicações da comunidade surda.

No bojo dos movimentos reivindicatórios dos manifestantes, promovidos especialmente pelos usuários da língua de sinais, está a busca pelo deslocamento da condição de deficiência para a diferença ontológica - como elemento nucleador de uma mudança política, epistemológica e pedagógica de se entender o surdo e sua especificidade.

Do ponto de vista sociolinguístico e do multiculturalismo, essa petição se fundamenta no fato de as pessoas surdas, usuárias da língua de sinais, constituírem uma comunidade própria, encontrando respaldo na Lei no 10.436/2002 (Lei da Libras), que conforme enfatiza

\footnotetext{
Trata-se de um dos maiores sucessos brasileiros, em termos de políticas linguísticas, pois gerou, a partir da mobilização da comunidade surda, 0 reconhecimento de que Libras é uma língua, e não uma "linguagem", gerou o reconhecimento de direitos linguísticos da comunidade e, indiretamente, o reconhecimento de que há uma cultura surda e portanto, há um potencial instalado para que os surdos deixem de ser vistos, por parte do Estado e de outros setores da sociedade, pela ótica da deficiência, passando a ocupar o lugar que lhes é devido no contexto do pluriculturalismo e do plurilinguismo brasileiro. (OLIVEIRA, 2011, p. 323)
}

Essas ponderações foram fortalecidas pelas discussões do campo da Linguística Aplicada, especialmente, com estudos na área da Política Linguística. Balizados no princípio de que as línguas e os seus usos constituem o alicerce do desenvolvimento 
http://dx.doi.org/10.5902/1984686X38356

humano e do seu agir social, esses estudos fundamentam os movimentos das minorias linguísticas, as quais têm exercido pressão sobre o Estado, para que abandone o mito do monolinguismo e promova políticas de reconhecimento do plurilinguismo e, por conseguinte, das diferenças culturais, sociais e linguísticas que compõem a nação brasileira.

Nesse contexto, a definição e a introdução de políticas linguísticas endereçadas ao atendimento dos direitos linguísticos dos surdos, indígenas, descendentes da imigração, habitantes situados nas fronteiras e brasileiros nas diásporas, são conquistas congruentes com o projeto contra a manutenção da sociedade monolíngue sob o respaldo de um currículo universal e de práticas pedagógicas arraigadas na ideologia da língua única, oficial.

Ruiz (1984 apud OLIVEIRA, 2016) menciona que, na atualidade, as políticas linguísticas são conduzidas a partir de três campos de orientações distintos, os quais concebem a Língua como Problema, a Língua como Direito e a Língua como Recurso.

A orientação da Língua como Problema tem relação com o projeto de nacionalização, que, firmado pela ideologia da "unidade" concebe a oficialização de um idioma nacional e a introdução de programas monolíngues de ensino como os principais mecanismos para a consolidação e o fortalecimento do Estado-Nação.

A orientação que concebe a Língua como Direito acompanha o processo de democratização e reconhecimento dos direitos sociais e está associada com a defesa dos direitos linguísticos, a partir da planificação e planejamento de políticas linguísticas para o uso, difusão e fortalecimento das variedades linguísticas e, portanto, socioculturais coexistentes em um país.

Já a orientação que assume a Língua como Recurso emerge da vertiginosa mundialização que nos sugere conceituar a cultura global, e tem especial ligação com "[...] a internacionalização dos mercados, do fluxo de pessoas nas migrações internacionais, dos fluxos da informação e do conhecimento na internet, em forma digital." (OLIVEIRA, 2016, p. 396). Nas duas últimas décadas, políticas linguísticas orientadas pelo campo da Língua como Recurso vêm ganhando um espaço proeminente nas discussões que valorizam a educação bilíngue, no contexto escolar brasileiro, impondo-nos a necessidade de um debate acerca das concepções de educação bilíngue para estudantes surdos, bem 
http://dx.doi.org/10.5902/1984686X38356

como do valor atribuído à língua de sinais e à Língua Portuguesa, nas políticas linguísticas da Libras e nas políticas de educação de surdos.

Sob o respaldo da orientação que concebe a Língua como Direito, reiteramos a reivindicação do movimento surdo por modos de organização da oferta da educação bilíngue empenhados em admitir a diferença promovida pela experiência da surdez e sua especificidade. Tal exigência nos convoca a considerar a necessidade de providências, como disponibilização de ambientes linguísticos adequados ao desenvolvimento e aprendizagem em e da língua de sinais; definição de currículos que considerem as diferenças ontológicas, linguísticas e culturais, favorecendo a receptividade e a viabilização da coexistência de duas línguas (Libras e Língua Portuguesa) e de formas distintas de vivenciar o mundo, no interior da escola.

É nesse sentido que o presente texto convida o leitor para o compartilhamento de um diálogo em torno do panorama nacional referente à composição do quadro de profissionais destinados ao atendimento educacional dos estudantes surdos, traçado a partir da investigação dos dispositivos contidos no Plano Nacional de Educação (PNE2014), nos Planos Estaduais e Distrital de Educação (PEE e PDE) e demais documentos a eles associados.

Ao tomar as concepções de educação bilíngue e o valor atribuído à língua de sinais e à Língua Portuguesa como objetos centrais desse debate, consideramos que a composição do quadro funcional e o estabelecimento do perfil dos profissionais destinados ao ensino em Libras e da Libras podem evidenciar elementos capazes de fundamentar uma política nacional de educação bilíngue (Libras/Língua Portuguesa) atenta aos direitos linguísticos das pessoas surdas inscritas no sistema de ensino brasileiro, na medida em que procederem ao deslocamento do olhar para os surdos sobre seus ouvidos, buscando direcioná-lo sobre suas mãos:

[...] olhar que remete a uma visão socioantropológica e multicultural da pessoa surda; um olhar que identifica os surdos como membros de uma comunidade linguística minoritária, com uma língua absolutamente plena, e características essencialmente visuais que acarretam a assimilação do mundo e do conhecimento visualmente. (NASCIMENTO; COSTA, 2014, p. 170).

Para instaurar o diálogo proposto, o artigo está dividido em três seções. Inicialmente, apresentamos as prerrogativas dos dispositivos federais vigentes, no que diz respeito ao perfil dos profissionais - formação, função e lócus de atuação, bem como a incumbência 
http://dx.doi.org/10.5902/1984686X38356

de provimento dos cargos pelos sistemas de ensino. Na segunda seção, expomos os procedimentos empregados para a coleta dos dados e para a localização das propostas e composição do panorama nacional relativo ao quadro funcional destinado ao atendimento linguístico e educacional dos surdos. Na terceira e última seção, procedemos a relação entre a descrição do perfil profissional indicado pelas políticas de educação bilíngue, no país, e os enunciados contidos nos textos investigados e demais dispositivos oficiais a eles associados, buscando problematizar propostas que concebem a Libras como recurso para o ensino em português, de sorte a enfatizar disposições que têm a língua de sinais como língua constitutiva das pessoas surdas as quais integram o sistema de ensino brasileiro.

\section{O provimento de cargos para oferta da educação bilíngue - Libras e Língua Portuguesa: prerrogativas federais}

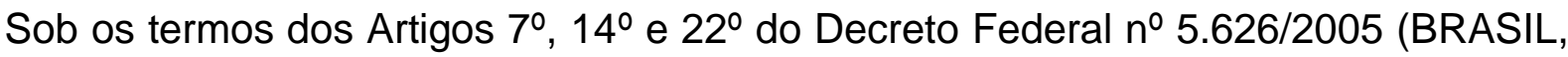
2005), entre as providências a serem tomadas pelas instituições federais de ensino para garantir o acesso dos estudantes surdos à comunicação, à informação e ao atendimento educacional especializado nos processos seletivos, nas atividades e nos conteúdos curriculares desenvolvidos em todos os níveis, etapas e modalidades de educação, assim como para a oferta da educação bilíngue na Educação Infantil e nos anos iniciais do Ensino Fundamental, está a contratação de: a) professor de Libras ou instrutor de Libras, prioritariamente surdo; b) tradutor e intérprete de Libras-Língua Portuguesa; c) professor para o ensino de Língua Portuguesa como segunda língua para pessoas surdas; d) professor regente de classe com conhecimento acerca da singularidade linguística manifestada pelos alunos surdos; e) professor bilíngue.

Em consonância com os documentos que regem a política educacional inclusiva (BRASIL, 2008; 2017), acrescenta-se também a admissão do professor do Atendimento Educacional Especializado (AEE), o qual tem por base uma formação generalista e, no caso específico do atendimento aos estudantes surdos, deve desempenhar o ensino da Libras e da Língua Portuguesa na modalidade escrita, a serem oferecidos de maneira complementar e em horário distinto ao da escolarização, prioritariamente nas salas de recursos multifuncionais da própria escola ou em centros de atendimento educacional especializado (BRASIL, 2017). 
http://dx.doi.org/10.5902/1984686X38356

Com o respaldo do Artigo 28 (§ $\left.2^{\circ}\right)$ da Lei Federal nº 13.146/2015, que institui a "Lei Brasileira de Inclusão da Pessoa com Deficiência (Estatuto da Pessoa com Deficiência)", espera-se ainda que, no prazo de 48 meses, contados a partir da data em que respectivo dispositivo legal entrou em vigor, o poder público assegure a disponibilização de intérpretes e tradutores de Libras com titulação de, no mínimo, nível médio completo e certificado de proficiência na Libras, para atuar na educação básica, e com titulação de nível superior, com habilitação, prioritariamente, em Tradução e Interpretação em Libras, para interpretar nas salas de aula dos cursos de graduação e pós-graduação, no âmbito das instituições públicas e privadas de ensino (BRASIL, 2015).

Ao estabelecer a relação dialógica com e entre os dispositivos supracitados, fica evidente que, no âmbito das políticas federais, a concessão de graus de importância direcionados à Libras é diferenciada, o que, consequentemente, ocasiona uma compreensão distinta a propósito de quem deva atuar nas instituições de ensino, com vistas à garantia da educação bilíngue e, portanto, do atendimento às demandas linguísticas e educacionais específicas dos estudantes surdos e/ou familiares que optarem pela presença da Libras e da Língua Portuguesa como línguas de instrução, no desenvolvimento de todo seu processo de ensino.

Referente a esse contrassenso, Lodi (2005), Thoma (2012) e Lacerda, Albres e Drago (2013) asseveram que, quando isolados e convivendo apenas com ouvintes, estudantes surdos tendem a se olhar e se narrar de modo negativo, como seres incompletos, inferiores e deficitários. Nesse sentido, analisam que a preferência por instrutores e professores surdos para atuar no ensino da Libras, em Libras, seja um critério a ser priorizado pelos sistemas de ensino no ato de seleção e contratação, não só por eles potencializarem o uso da língua de sinais em todos os espaços das instituições de ensino, mas, principalmente, por proporcionarem o encontro surdo-surdo e a construção de uma percepção positiva da experiência de ser surdo por todos os estudantes.

Em contrapartida, Guedes (2010) e Lacerda, Albres e Drago (2013) avaliam que a oferta do ensino da Libras e da Língua Portuguesa na modalidade escrita, como atividades de complementação curricular do AEE, não gera melhores condições de aprendizagem para o estudante surdo. Afinal, as dificuldades educacionais dos surdos não são inerentes à experiência da surdez e, por isso, terão menos chances de serem 
http://dx.doi.org/10.5902/1984686X38356

removidas perante a oferta de um ensino controlado da Libras, sob prescrições de horários, atividades formais, sequências preestabelecidas, sendo frequentemente mediado por modelos linguísticos estereotipados.

Todavia, Silva (2018) demonstra que, na tentativa de responder às recomendações contidas no Decreto Federal n 5.626/2005 e na política nacional de educação inclusiva (BRASIL 2008; BRASIL, 2009a; BRASIL, 2009b; BRASIL, 2011), o atual Plano Nacional de Educação (PNE-2014) acomoda concepções incompatíveis, no que diz respeito à maneira como a educação bilíngue em Libras e Língua Portuguesa deva ser organizada e assegurada pelo Estado.

À vista disso, quanto à composição do quadro de profissionais habilitados para atender às demandas da oferta da educação bilíngue, preconiza:

4.13) apoiar a ampliação das equipes de profissionais da educação [...], garantindo a oferta de professores (as) do atendimento educacional especializado, profissionais de apoio ou auxiliares, tradutores (as) $e$ intérpretes de Libras, guias-intérpretes para surdos-cegos, professores de Libras, prioritariamente surdos, e professores bilíngues. (BRASIL, 2014, s/p - grifos das autoras).

Ao acomodar, no mesmo enunciado, a garantia da oferta de professores do AEE e de tradutores e intérpretes de Libras, professores de Libras, prioritariamente surdos e professores bilíngues, o Plano nos remete às seguintes questões: em que medida essas possibilidades antagônicas intervêm para que a tomada de providências, por parte dos sistemas educacionais de ensino, se coadune com a observância dos direitos linguísticos dos surdos, usuários das Libras, e com a consolidação de uma proposta educacional bilíngue em Libras e Língua Portuguesa? Como tais prerrogativas têm permitido àqueles que se constituem na experiência da surdez se afirmarem surdos e terem reconhecidas suas singularidades e suas potencialidades de aprender?

Afinal, é possível indagar:

Que é, pois, que, nos conteúdos vivos da cultura, nas significações que atualmente têm poder de interpelar nossos pensamentos e de regular nossas existências, pode ser considerado como tendo um "valor educativo" ou uma pertinência social suficiente para justificar os gastos de todos os tipos exigidos por um ensino sistemático e mantido pelo Estado? (FORQUIN, 1993, p. 16).

Isso posto, convém observar que a "Convenção Internacional sobre os Direitos das Pessoas com Deficiência" tem como propósito promover, proteger e assegurar o exercício 
http://dx.doi.org/10.5902/1984686X38356

pleno e equitativo de todos os direitos humanos e liberdades fundamentais por todas as pessoas com deficiência e promover o respeito pela sua dignidade inerente, mas preconiza que as modificações e os ajustes necessários e adequados a serem providenciados, para que as pessoas com deficiência possam gozar ou exercer, em igualdade de oportunidades com as demais pessoas, não devem acarretar ônus desproporcional ou indevido (BRASIL, 2009a).

Diante de tais circunstâncias, é preciso reconhecer que o investimento na formação, seleção e contratação de profissionais com os perfis específicos exigidos pelo Decreto Federal $n^{\circ}$ 5.626/2005 - 1) professores de Libras, prioritariamente surdos, com formação de nível superior, em curso de licenciatura plena em Letras - Libras ou em Letras Libras/Língua Portuguesa como segunda, para atuar nas séries finais do Ensino Fundamental, Ensino Médio e na Educação Superior; 2) professores bilíngues, com formação em curso de Pedagogia ou curso normal superior, em que Libras e Língua Portuguesa escrita tenham constituído línguas de instrução, viabilizando a formação bilíngue, para atuar na educação infantil e nos anos iniciais do Ensino Fundamental; 3) instrutores de Libras com formação de nível médio, em cursos de educação profissional, cursos de formação continuada promovidos por instituições de ensino superior, cursos de formação continuada promovidos por instituições credenciadas pelas respectivas Secretarias de Educação ou cursos promovidos por organizações da sociedade civil representativa da comunidade surda, desde que certificados pelas instituições de Ensino Superior e/ou pelas Secretarias de Educação; e 4) tradutores e intérpretes de LibrasLíngua Portuguesa, com formação de nível superior em Tradução e Interpretação, com habilitação em Libras-Língua Portuguesa para atuar no Ensino Superior ou com Ensino Médio completo e certificado de proficiência na Libras, para atuar na Educação Básica corresponde a um custeio desproporcional por parte do poder público, em comparação com o investimento feito para garantir professores do AEE e tradutores e intérpretes da Libras com a devida formação, como previsto nos documentos que regem a política de educação inclusiva.

Nesse sentido, considerando que, de acordo com o Decreto Federal no 5.626/2005, é dever das instituições federais cumprir com os termos estabelecidos no que concerne ao provimento de cargos para atuar na educação de surdos, cabendo às instituições privadas e públicas dos sistemas de ensino estadual, municipal e do Distrito Federal 
http://dx.doi.org/10.5902/1984686X38356

buscar implementar tais medidas, como meio de assegurar atendimento educacional especializado ao referido público (BRASIL, 2005), este texto se atém às seguintes questões:

Se o PNE-2014 tem, como dois de seus propósitos, garantir a unidade das políticas educacionais brasileiras e consolidar um sistema de ensino nacional, e se, para isso, a União, os estados, o Distrito Federal e os municípios devem atuar em regime de colaboração (BRASIL, 1996), sendo dever dos estados, do Distrito Federal e dos municípios elaborar seus respectivos planos de educação em consonância com as diretrizes, metas e estratégias previstas no PNE (BRASIL; 1988, 2014), como os autores dos atuais Planos Estaduais e Distrital de Educação (PEEs e PDE) procederam à recontextualização da estratégia 4.13 do PNE-2014, com vistas à garantia do provimento dos cargos para atender à demanda do processo de escolarização dos estudantes surdos e à promoção da oferta da educação bilíngue, nos sistemas estaduais e distrital de ensino? Em que medida as tendências e as exceções, evidenciadas a partir do estabelecimento da relação dialógica com e entre os textos, podem contribuir com a avaliação e planejamento de ações, em busca da consolidação dos direitos linguísticos dos surdos e de uma política nacional de educação bilíngue, em que Libras e Língua Portuguesa sejam as línguas de instrução, no desenvolvimento de todo o processo educacional?

\section{Trajetória percorrida para o desenvolvimento da investigação}

A busca por respostas às indagações destacadas mobilizou o cumprimento da seguinte trajetória de pesquisa:

1) Coleta dos 26 Planos Estaduais de Educação (PEE) e do Plano Distrital de Educação (PDE) na página "PNE em movimento", disponível no portal do Ministério da Educação (MEC);

2) Leitura das estratégias ligadas à Meta da "Educação Especial/Inclusiva" dos PEE e PDE investigados.

3) Seleção e grifo dos enunciados das estratégias alusivos à estratégia 4.13 do PNE-2014, ou seja, a composição da equipe de profissionais especializados destinados ao atendimento das demandas do processo de escolarização dos estudantes surdos e a efetivação da oferta da educação bilíngue Libras-Língua Portuguesa. 
4) Cópia e transferência dos enunciados localizados em 25 dos 27 Planos de Educação investigados para um arquivo no Editor de textos Word, no qual foram listados um a um, abaixo do enunciado da estratégia 4.13 do PNE-2014, tendo como critério de organização a relação de nomes dos entes federados, dispostos em ordem alfabética.

5) Seleção, grifo, cópia e transferência de outras estratégias relativas ao tema para o arquivo do Editor de textos Word, as quais foram localizadas em alguns dos Planos de Educação investigados, num segundo movimento de busca, que envolveu a leitura integral dos referidos documentos, destacando a opção de alguns sistemas de ensino pela adoção de medidas adicionais, em âmbito local.

6) Com a finalidade de agrupar os enunciados, optou-se por compor mapas do Brasil, respeitando a divisão geográfica por estados, a fim de situar as respectivas localidades em que foram produzidas as estratégias e, ao mesmo tempo, estabelecer a relação entre o local e o contexto mais global da organização das políticas de educação bilíngue, o que permitiu traçar o panorama nacional relativo à composição do quadro de profissionais destinados a suprir a demanda do processo de escolarização dos estudantes surdos nos respectivos sistemas educacionais de ensino, além de evidenciar o hibridismo das propostas, as tendências e as exceções.

Desenvolvida por Silva (2018), a técnica de construção dos mapas envolveu uma minuciosa tarefa de edição gráfica, com a utilização do software CorelDraw, um programa desenvolvido para ilustração e design gráfico. De modo a compor o mapa do Brasil divisão por estados, primeiramente, todos os contornos dos limites territoriais foram traçados no software, depois, as 27 unidades federativas foram desagrupadas, a fim de que cada uma delas pudesse ser preenchida individualmente, com cor equivalente à cor da legenda.

Para melhor visualização das tendências e exceções, optou-se por determinar uma paleta de cores, relacionando uma cor com cada uma das unidades federativas, e também para identificar o PNE-2014, necessária para indicar a situação de reprodução da estratégia 4.13 nos demais Planos de educação investigados. No caso de coincidência entre as estratégias dos PEE e PDE, a cor de preenchimento foi a mesma para unidades federativas com enunciados análogos.

Como existe uma oscilação na numeração das metas e das estratégias, nos PEE e PDE investigados, os excertos foram dispostos nas legendas, acompanhados das siglas 
http://dx.doi.org/10.5902/1984686X38356

das unidades federativas e do número da meta e da estratégia correspondentes, o que facilita a localização dos enunciados nos respectivos documentos, caso haja interesse do leitor.

A opção pela elaboração dos mapas foi a alternativa encontrada para ativar o diálogo em torno das propostas apresentadas pelos sistemas educacionais, quanto à composição da equipe de profissionais destinada ao ensino em Libras e da Libras e, portanto, à concretização de uma proposta educacional bilíngue em Libras e Língua Portuguesa, atenta aos direitos linguísticos dos surdos.

O propósito de promover a relação dialógica com e entre os enunciados teve como parâmetro os fundamentos da teoria enunciativo-discursiva de Bakhtin e o círculo, para quem o texto escrito é um ato de fala impresso orientado em função das intervenções anteriores na mesma esfera de atividade (VOLOCHÍNOV; BAKHTIN, 2014), de sorte que

[...] o enunciado, enquanto materialidade discursiva, não se fecha em si mesmo, visto que se constitui como tal no interminável diálogo entre discursos já-ditos ou ainda não ditos, abrigando uma multiplicidade de vozes, ou seja, posições ideológicas, que estabelecem entre si relações de acordo ou desacordo, aceitação ou recusa, harmonia ou conflito. (NUNES, 2018, p. 119).

Sob tais ponderações, por entender que as propostas relativas ao provimento de cargos a fim de suprir as demandas de escolarização dos estudantes surdos, fixadas nas estratégias do PNE-2014, assim como dos atuais PEEs e do PDE, não são restritas a eles, mas estão aquém e além das palavras que compõem os documentos em questão, foi preciso estabelecer a interlocução com e entre os excertos deles extraídos e elencados nos mapas, e outros textos que se articulam a eles. Assim, foi possível obter resultados que serão apresentados a seguir.

\section{Panorama da oferta da educação bilíngue: composição do quadro}

Conforme Ball (2001), na transferência de políticas de uma esfera administrativa para outra, elas são retrabalhadas, aperfeiçoadas, ensaiadas, crivadas de nuances e moduladas por complexas influências, produção e disseminação de textos, configurando constantes "processos de recontextualização". Em outras palavras, as políticas, compreendidas aqui como intervenções textuais, passam por constantes movimentos de deslocação e recolocação, os quais implicam transformações motivadas pela 
http://dx.doi.org/10.5902/1984686X38356

incorporação de outros discursos, interesses e condições específicas, pertencentes ao contexto em que se inserem.

Tendo em vista que, no processo de recontextualização do PNE-2014, para composição dos respectivos PEEs e PDE, a estratégia 4.13 - referente à composição da equipe de profissionais para o atendimento educacional dos estudantes surdos - foi reiterada em 25 dos 27 Planos de Educação mencionados; com base nos excertos elencados no mapa apresentado a seguir, analisa-se em que medida as propostas previstas nos PEEs e no PDE coincidem ou contrastam com as proposições do PNE2014, o quanto as equipes de profissionais situadas nos Planos de Educação investigados correspondem às determinações do Decreto Federal n0 5.626/2005, e quais os limites e possibilidades das medidas previstas nos documentos em questão, para a consolidação de uma proposta educacional atenta aos direitos linguísticos e à condição bilíngue prescrita aos estudantes surdos, no Brasil.

Figura 1 - Equipe de profissionais para o atendimento educacional dos estudantes surdos nos sistemas estaduais e distrital de ensino

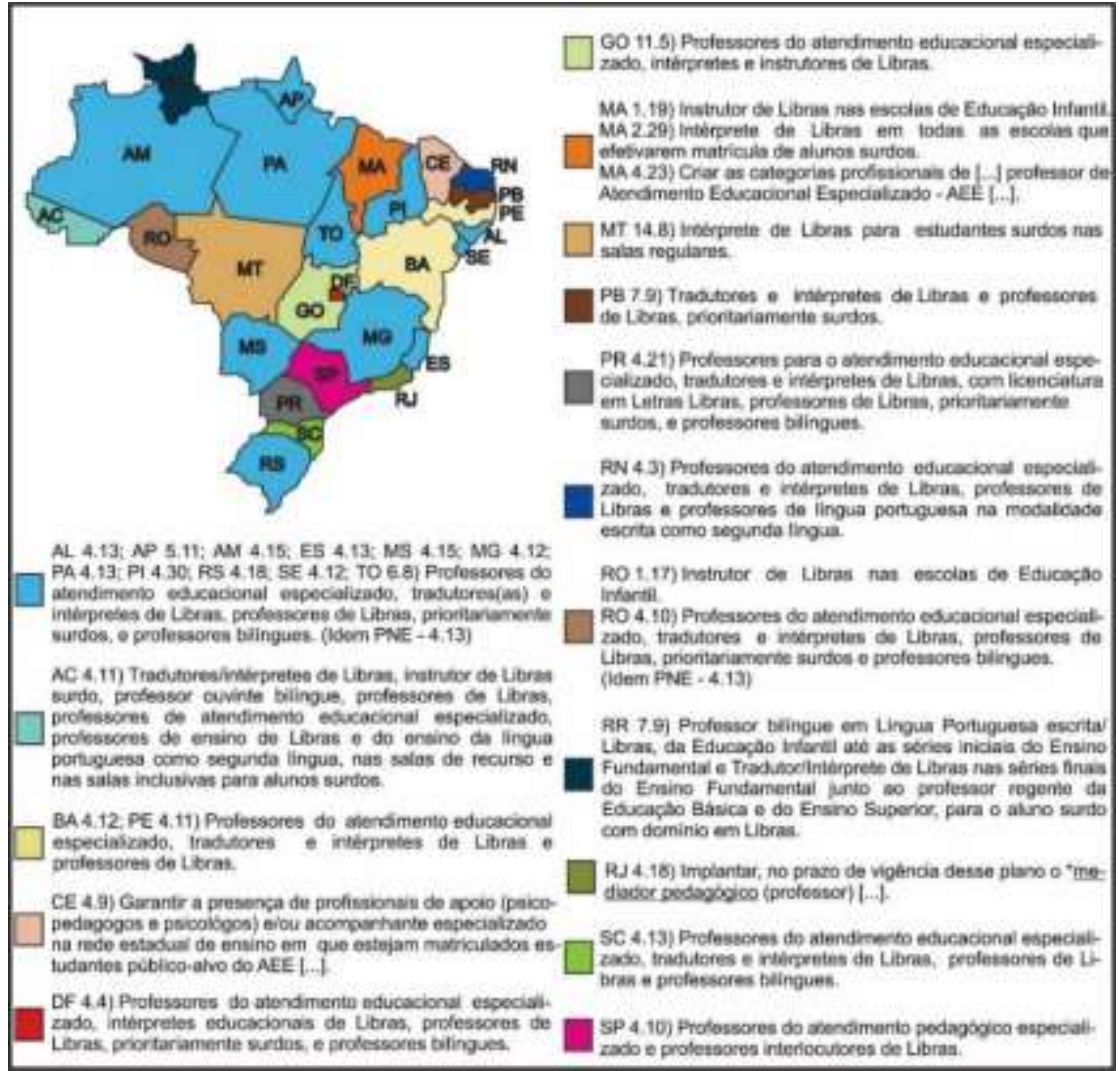

Fonte: Adaptado de Silva (2018). 
http://dx.doi.org/10.5902/1984686X38356

Direcionando o olhar para o mapa, é possível constatar que 11 dos 27 entes federados optaram por reproduzir o enunciado da estratégia 4.13 do PNE-2014, em seus respectivos PEEs. Tal escolha exige que as instituições de ensino vinculadas às Secretarias de Educação dos referidos estados - Alagoas, Amapá, Amazonas, Espírito Santo, Mato Grosso do Sul, Minas Gerais, Pará, Piauí, Rio Grande do Sul, Sergipe e Tocantins - sejam contempladas com a oferta de professores do AEE, tradutores e intérpretes de Libras, professores de Libras, prioritariamente surdos, e professores bilíngues.

Cabe salientar que a contratação dos profissionais com a qualificação compatível a função exige da União, bem como dos estados em questão, prever meios para assegurar a criação ou a ampliação da oferta de cursos de licenciatura plena em Letras-Libras ou em Letras-Libras/Língua Portuguesa como segunda língua, cursos de Pedagogia Bilíngue, nos quais Libras e Língua Portuguesa sejam as línguas de instrução, e cursos de Tradução e Interpretação de Libras-Língua Portuguesa (BRASIL, 2005). Caso contrário, a possibilidade de esses sistemas de ensino ampliarem suas equipes profissionais se torna inconsistente, pois, de acordo com Lacerda, Albres e Drago (2013) e Kumada (2017), a oferta desses tipos de curso ainda é incipiente, no Brasil.

Nesse sentido, como poderá ser observado a seguir, no mapa da Figura 2, as proposições dos Planos de Educação, quanto à oferta de cursos para a formação de tradutores e intérpretes de Libras, professores de Libras e professores bilíngues habilitados para o ensino da Libras/Português, trazem muitas incertezas quanto à promessa dos entes federados de suprir a demanda das instituições educacionais, no que concerne à garantia do provimento de profissionais especializados para atender aos direitos linguísticos dos surdos e promover a oferta da educação bilíngue em Libras e Língua Portuguesa. 
Figura 2 - Estratégias para formação de profissionais especializados nos Planos Estaduais de Educação (PEE)

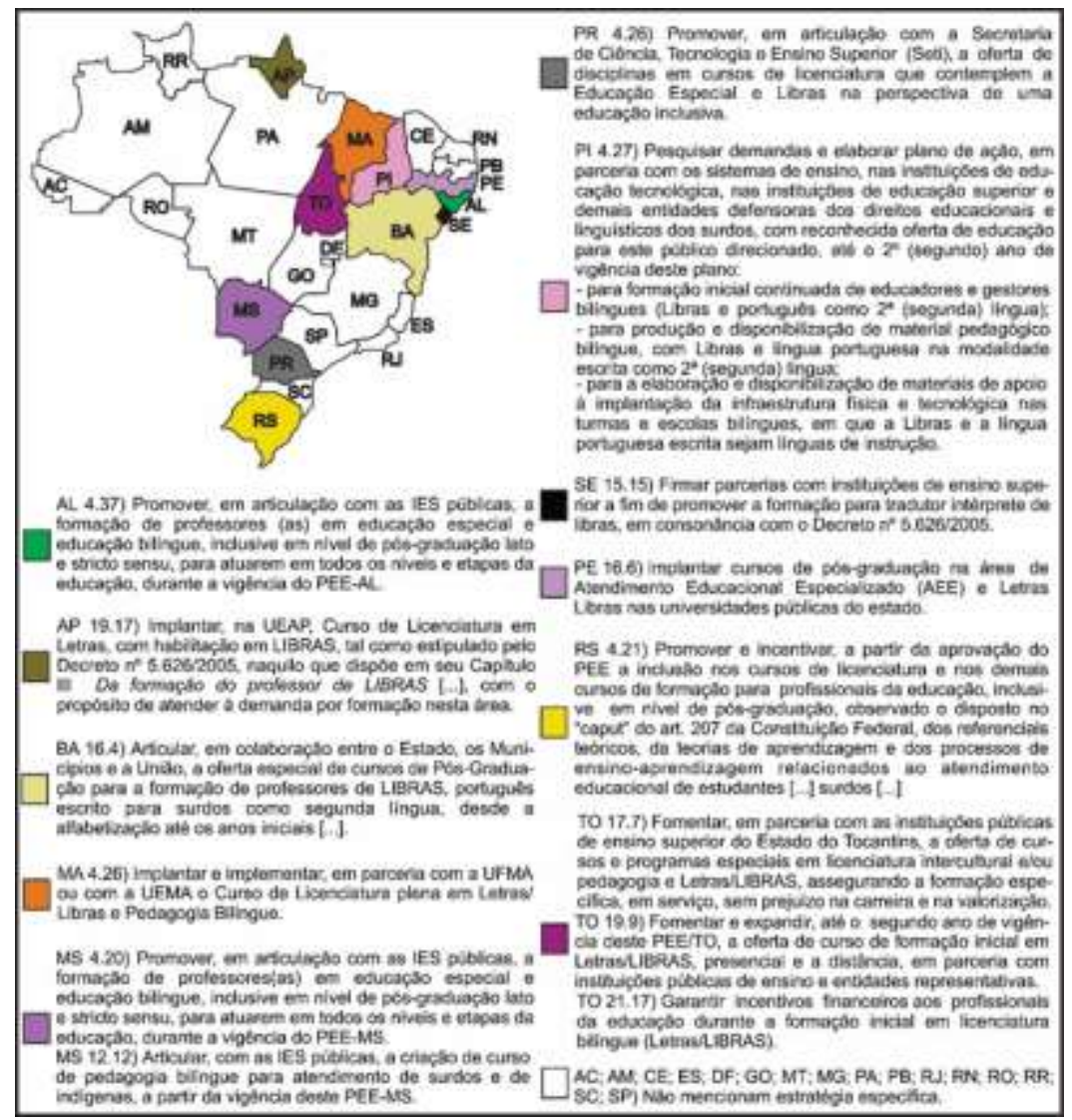

Fonte: Adaptado de Silva, (2018).

Recorrendo ao mapa da Figura 2, é possível constatar que, embora os PEEs do Amazonas, Espírito Santo e Pará anunciem a ampliação de suas equipes profissionais, com a contratação de professores do AEE, tradutores e intérpretes de Libras, professores de Libras, prioritariamente surdos e professores bilíngues, em consonância com a estratégia 4.13 do PNE-2014, não mencionam estratégias relativas à providência de criação ou ampliação da oferta de cursos de formação inicial.

Nessa perspectiva, entre os 27 estados que preveem a ampliação da equipe de profissionais de seus respectivos sistemas de ensino, destacamos a coerência das proposições dos PEEs de Alagoas, Amapá, Bahia, Maranhão, Mato Grosso do Sul, Paraná, Pernambuco, Piauí, Rio Grande do Sul, Sergipe e Tocantins, uma vez que a premissa de garantia de provimento dos cargos específicos para o atendimento à 
http://dx.doi.org/10.5902/1984686X38356

demanda de escolarização dos estudantes surdos está alinhada com a providência de meios para garantir a formação dos profissionais.

Ademais, os referidos PEEs dialogam com os termos do Decreto Federal ํㅡㄴ 5.626/2005, o qual estabelece:

Art. $4^{\circ} \mathrm{A}$ formação de docentes para o ensino de Libras nas séries finais do ensino fundamental, no ensino médio e na educação superior deve ser realizada em nível superior, em curso de graduação de licenciatura plena em Letras: Libras ou em Letras: Libras/Língua Portuguesa como segunda língua.

Parágrafo único. As pessoas surdas terão prioridade nos cursos de formação previstos no caput.

Art. $5^{\circ} \mathrm{A}$ formação de docentes para o ensino de Libras na educação infantil e nos anos iniciais do ensino fundamental deve ser realizada em curso de Pedagogia ou curso normal superior, em que Libras e Língua Portuguesa escrita tenham constituído línguas de instrução, viabilizando a formação bilíngüe.

$\S 1^{\circ}$ Admite-se como formação mínima de docentes para o ensino de Libras na educação infantil e nos anos iniciais do ensino fundamental, a formação ofertada em nível médio na modalidade normal, que viabilizar a formação bilíngüe, referida no caput.

$\S 2^{\circ}$ As pessoas surdas terão prioridade nos cursos de formação previstos no caput. (BRASIL, 2005, s/p).

E prossegue:

Art. 11 O Ministério da Educação promoverá, a partir da publicação deste Decreto, programas específicos para a criação de cursos de graduação:

I - para formação de professores surdos e ouvintes, para a educação infantil e anos iniciais do ensino fundamental, que viabilize a educação bilíngue: Libras - Língua Portuguesa como segunda língua;

II - de licenciatura em Letras: Libras ou em Letras: Libras/Língua Portuguesa, como segunda língua para surdos;

III - de formação em Tradução e Interpretação de Libras - Língua Portuguesa. (BRASIL, 2005, s/p).

No que tange às modificações da estratégia 4.13 do PNE-2014, derivadas do processo de recontextualização que culminou na composição dos 26 PEEs e do PDE investigados, constataram-se variações quanto à composição do quadro funcional, as quais seguem elencadas no Quadro 1: 
http://dx.doi.org/10.5902/1984686X38356

Quadro 1 - Equipe de profissionais para o atendimento educacional dos estudantes surdos nos sistemas estaduais e distrital de ensino

\begin{tabular}{|c|c|c|}
\hline Cargo/função & $\begin{array}{l}\text { Plano de Educação em que foi } \\
\text { indicado }\end{array}$ & $\begin{array}{l}\text { Total de } \\
\text { indicações }\end{array}$ \\
\hline $\begin{array}{l}\text { Professor do Atendimento } \\
\text { Educacional Especializado (AEE) }\end{array}$ & $\begin{array}{l}\text { AC, AL, AP, AM, BA, DF, ES, GO, MA, } \\
\text { MS, MG, PA, PR, PE, PI, RN, RS, RO, } \\
\text { SC, SE, TO }\end{array}$ & 21 \\
\hline Tradutores e intérpretes de Libras & $\begin{array}{l}\text { AC, AL, AP, AM, BA, ES, MS, MG, PA, } \\
\text { PB, PE, PI, RN, RS, RO, RR, SC, SE, } \\
\text { TO }\end{array}$ & 19 \\
\hline Intérprete de Libras & GO, MA, MT & 3 \\
\hline $\begin{array}{l}\text { Tradutor e intérprete de Libras, } \\
\text { com licenciatura em Letras/Libras }\end{array}$ & PR & 1 \\
\hline Intérprete educacional de Libras & DF & 1 \\
\hline Professor interlocutor de Libras & SP & 1 \\
\hline $\begin{array}{lcc}\text { Professor } & \text { de } & \text { Libras, } \\
\text { prioritariamente surdo } & \\
\end{array}$ & $\begin{array}{l}\text { AL, AP, AM, DF, ES, MS, MG, PA, PB, } \\
\text { PR, PI, RS, RO, SE, TO }\end{array}$ & 15 \\
\hline Professor de Libras & $A C, B A, P E, R N, S C$ & 5 \\
\hline Instrutor de Libras surdo & $A C$ & 1 \\
\hline $\begin{array}{l}\text { Instrutor de Libras nas escolas de } \\
\text { Educação Infantil }\end{array}$ & $\mathrm{MA}, \mathrm{RO}$ & 2 \\
\hline Instrutor de Libras & GO & 1 \\
\hline Professor bilíngue & $\begin{array}{l}\text { AC, AL, AP, AM, DF, ES, MS, MG, PA, } \\
\text { PR, PI, RS, RO, RR, SC, SE, TO }\end{array}$ & 17 \\
\hline $\begin{array}{l}\text { Professor para o ensino de Libras } \\
\text { e de Língua Portuguesa na } \\
\text { modalidade escrita como segunda } \\
\text { língua }\end{array}$ & $\mathrm{AC}, \mathrm{RN}$ & 2 \\
\hline $\begin{array}{l}\text { Professor do } \quad \text { atendimento } \\
\text { pedagógico especializado }\end{array}$ & SP & 1 \\
\hline Mediador pedagógico (professor) & $\mathrm{RJ}$ & 1 \\
\hline Acompanhante especializado & $\mathrm{CE}$ & 1 \\
\hline
\end{tabular}

Fonte: Adaptado de Silva (2018).

Em observância às recomendações da política educacional inclusiva (BRASIL, 2008, 2009b), reiteradas também pelo PNE-2014, 21 dos 27 PEEs examinados denotam que seus respectivos sistemas educacionais pactuam com o dever de garantir a incorporação de professores do AEE em seus quadros funcionais.

Ao profissional em questão, cuja formação inicial é generalista, compete o desenvolvimento de atividades que atendam às demandas de escolarização de todos os estudantes público-alvo da Educação Especial, a saber: alunos com deficiências, alunos com transtornos globais do desenvolvimento e alunos com altas habilidades ou superdotação (BRASIL, 2008, 2009b, 2011). 
http://dx.doi.org/10.5902/1984686X38356

Assim, fica a cargo do professor do AEE o ensino do Sistema Braille, de técnicas de orientação e mobilidade, de uso de recursos ópticos e não ópticos, da Libras, da comunicação alternativa e aumentativa (CAA), das técnicas de cálculo no Soroban, da usabilidade e das funcionalidades da informática acessível e da Língua Portuguesa na modalidade escrita, além da aplicação de estratégias para autonomia no ambiente escolar, para o desenvolvimento de processos mentais e para enriquecimento curricular, a serem realizadas em horário distinto ao da escolarização, prioritariamente nas salas de recursos multifuncionais da própria escola ou em centros de Atendimento Educacional Especializado (BRASIL, 2017).

Quanto ao cargo/função de "professor do atendimento pedagógico especializado", mencionado na estratégia 4.10 do PEE-SP, também diz respeito à contratação do profissional responsável pela oferta do AEE, o qual pode atuar em Sala de Recursos, na modalidade itinerante ou em Classes Regidas por Professor Especializado (CRPE), prestando atendimento, exclusivamente, no contraturno da frequência do aluno às classes comuns do ensino regular (SÃO PAULO, 2017).

De acordo com a "Instrução da Coordenadoria de Gestão da Educação Básica (CGEB)", expedida em 14 de janeiro de 2015, o professor do atendimento pedagógico especializado na área da deficiência auditiva/surdez tem como atribuições específicas:

8.1.1- elaborar o Plano de Atendimento Individual (PAI), para cada aluno que frequentar a Sala de Recursos de surdez/deficiência auditiva;

8.1.2- orientar os professores da classe comum, durante as aulas, a acomodar o aluno na posição mais adequada da sala, para facilitar a visualização do professor, professor interlocutor e a lousa;

8.1.3- atender aos alunos nos aspectos da linguagem, estimulando a comunicação e dissipando as dificuldades impeditivas de aprendizagem pelos quais os alunos são encaminhados. Para tanto, deverá trabalhar:

8.1.3.1 - o Ensino da Língua Brasileira de Sinais - Libras, como primeira língua (L1);

8.1.3.2- o Ensino da Língua Portuguesa, na modalidade escrita, como segunda língua (L2);

8.1.4- produzir e adequar materiais didáticos e pedagógicos, de acordo com as necessidades do aluno, utilizando o apoio visual e em Libras, entre outros;

8.1.5- oferecer apoio pedagógico ao aluno contribuindo com 0 desenvolvimento de sua aprendizagem. (SÃO PAULO, 2015, s/p).

Ora, a fim de exercer a função, o referido profissional deve comprovar formação na área da deficiência auditiva/surdez, em conformidade com os seguintes parâmetros: 
http://dx.doi.org/10.5902/1984686X38356

I - licenciatura Plena em Educação Especial, conforme disposto no Parecer CEE 65/2015;

II - licenciatura Plena em Pedagogia, com habilitação específica na área da necessidade;

III - outras licenciaturas - Plena, com pós-graduação stricto sensu, Mestrado ou Doutorado, na área da necessidade especial;

IV - licenciatura Plena em Pedagogia ou Curso Normal Superior, com curso de Especialização realizado nos termos da Deliberação CEE 112/2012;

$\mathrm{V}$ - qualquer Licenciatura Plena, com curso de Especialização realizado nos termos da Deliberação CEE 112/2012 [...] (SÃO PAULO, 2017, s/p).

Segundo Fernandes e Moreira (2014) e Lodi e Albuquerque (2016), essa planificação da oferta da educação bilíngue não confere importância à língua de sinais, como língua de status equivalente à língua oral, na dialogia que envolve estudantes surdos e ouvintes, nas escolas. Configura-se, por conseguinte, uma lógica simplista, dando a entender que a presença velada e controlada da Libras nas salas de recursos multifuncionais somente para os surdos assegura a inclusão, quando, na verdade, a despeito da presença da "língua" na escola, o olhar sobre os surdos permanece vinculado aos seus ouvidos, "[...] olhar esse que remete a uma visão patológica implicada numa intervenção medicalizante, como tentativa de aproximar o surdo de uma pessoa não surda" (NASCIMENTO; COSTA, 2014, p. 170), cuja língua preponderante ainda é o português falado e escrito, reiterado pelo discurso da consolidação de espaços pseudobilíngues, os quais deslocam a Libras para a condição de recurso.

Acerca da investidura na contratação de tradutores e intérpretes de Libras, pode-se sustentar que tal escolha tem recíproca relação com as recomendações do Decreto Federal n 5.626/2005 e da "Política Nacional de Educação Especial na Perspectiva da Educação Inclusiva" (BRASIL, 2008), os quais determinam que a presença de tradutores e intérpretes de Libras-Língua Portuguesa seja assegurada nas instituições de ensino, com a finalidade de garantir a inclusão e o atendimento às necessidades educacionais dos estudantes surdos, sob a acepção de que a referida providência pode colaborar com a eliminação das barreiras comunicacionais que impedem a participação plena e efetiva desse alunado no processo educacional, em igualdade de condições com os demais estudantes (BRASIL, 2009a).

Sob tais ponderações, o Quadro 1 "Equipe de profissionais para o atendimento educacional dos estudantes surdos nos sistemas estaduais e distrital de ensino" evidencia que, salvo a distinção na denominação do cargo, 25 dos 27 Planos de Educação 
http://dx.doi.org/10.5902/1984686X38356

investigados indicam o provimento de profissionais para desempenhar a função de tradução e interpretação em Libras e Língua Portuguesa.

Todavia, sabendo que as diferentes denominações compreendem modos distintos de conceber as atribuições dos referidos profissionais, cumpre enfatizar que, segundo Theodor (1976), Silveira (2004) e Quadros (2004)

[...] os termos tradução e interpretação se complementam e, em certa medida, remetem à mesma tarefa: versar os conteúdos de uma dada língua para outra, buscando trazer neste processo os sentidos pretendidos, sem que eles se percam ou que sejam distorcidos no percurso. (THEODOR, 1976; SILVEIRA, 2004; QUADROS 2004 apud LACERDA, 2012, p. 252).

Por outro lado, Lacerda (2012) afirma que certos autores, como Rónai (1987) e Pagura (2003)

[...] defendem a ideia de que tradução e interpretação são conceitos que se remetem a tarefas distintas. Traduzir estaria ligado à tarefa de versar de uma língua para outra trabalhando com textos escritos. Desse modo, o tradutor teria tempo para ler, para refletir sobre as palavras utilizadas e os sentidos pretendidos e, ao traduzir para a língua alvo, poderia consultar dicionários, livros, pessoas na busca de trazer os sentidos pretendidos do modo mais adequado. Já interpretar está ligado à tarefa de versar de uma língua para outra nas relações interpessoais, trabalhando na simultaneidade, no curto espaço de tempo entre o ato de enunciar e o ato de dar acesso ao outro àquilo que foi enunciado. Assim, o intérprete trabalha nas relações sociais em ato, nas relações face a face, e deve tomar decisões rápidas sobre como versar um termo ou um sentido de uma língua para outra, sem ter tempo para consultas ou reflexões. (RÓNAI, 1987; PAGURA, 2003 apud LACERDA, 2012, p. 252).

No que concerne à exigência de contratação do tradutor e intérprete de Libras, com licenciatura em Letras/Libras, conforme enunciado na estratégia 4.21 do PEE-PR (Figura 1), é preciso considerar que, de acordo com o artigo 17 do Decreto Federal $\mathrm{n}^{\circ}$ 5.626/2005, “[a] formação do tradutor e intérprete de Libras - Língua Portuguesa deve efetivar-se por meio de curso superior de Tradução e Interpretação, com habilitação em Libras-Língua Portuguesa." (BRASIL, 2005, s/p). Conforme Lacerda (2012), uma leitura atenta do decreto evidencia que o referido documento define a necessidade de formação em curso superior, mas não determina qualquer tipo de vinculação com cursos de Letras. Nesse sentido, é preciso reconhecer que, embora exista uma tradição em outros países e em algumas universidades do Brasil de vincular a formação do profissional de tradutor e intérprete a cursos de Letras, essa escolha não é unânime: 
http://dx.doi.org/10.5902/1984686X38356

O mais importante é focalizar que a formação fundamental para o tradutor/intérprete vai além do conhecimento das línguas, que deve ser uma formação plural e interdisciplinar, visando a seu trânsito na polissemia das línguas, nas esferas de significação e nas possibilidades de atuação frente à difícil tarefa de tradução/interpretação. (LACERDA, 2012, p. 265).

No que tange às atribuições do tradutor e intérprete de Libras-Língua Portuguesa, a Lei Federal no 12.319/2010 indica que, no ambiente educacional, esse profissional tem as seguintes incumbências:
Art. $6^{\circ}$
$[\ldots]$
I - efetuar comunicação entre surdos e ouvintes, surdos e surdos, surdos e surdos-cegos, surdos-cegos e ouvintes, por meio da Libras para a língua oral e vice-versa;
II - interpretar, em Língua Brasileira de Sinais - Língua Portuguesa, as atividades didático-pedagógicas e culturais desenvolvidas nas instituições de ensino nos níveis fundamental, médio e superior, de forma a viabilizar o acesso aos conteúdos curriculares; [...] (BRASIL, 2010, s/p).

Entretanto, Lacerda (2012) enfatiza que a presença de um tradutor e intérprete de Libras na sala de aula não assegura que questões metodológicas sejam consideradas, assim como não traz a garantia de que o espaço socioeducacional, em geral, seja mais acessível, pois o estudante surdo pode permanecer às margens da vida escolar, usando uma língua restrita à sua relação com o intérprete de língua de sinais.

Ademais, a autora (2012) avalia que a atuação do intérprete, no espaço educacional, requer competências peculiares. Assim, admite ser favorável à regulamentação do cargo/função do intérprete educacional (IE), de sua formação e de suas competências, pois se compreende que o trabalho do intérprete no contexto educacional

[...] vai além de fazer escolhas ativas sobre o que deve traduzir, envolvendo também modos de tornar os conteúdos acessíveis para o aluno, ainda que implique solicitar ao professor que reformule sua aula, pois uma tradução correta do ponto de vista da linguística nem sempre é a melhor opção educacional para propiciar conhecimento, principalmente quando os alunos são crianças ainda em fase de aquisição da Libras. (LACERDA, 2012, p. 279).

Diante do exposto, deduz-se que a indicação singular de "intérpretes educacionais de Libras", realizada na estratégia 4.4 do PDE-DF, denota uma escolha mobilizada pelo reconhecimento da especificidade laboral que o contexto educacional requer desse profissional.

Concebida como uma exceção, destaca-se igualmente a indicação de "professores interlocutores de Libras", situada na estratégia 4.10 do PEE-SP. O referido cargo é 
http://dx.doi.org/10.5902/1984686X38356

regulamentado pela Resolução SE n 8, de 29 de janeiro de 2016, que "Dispõe sobre a atuação de docentes com habilitação/qualificação na Língua Brasileira de Sinais (Libras), nas escolas da rede estadual de ensino, e dá providências correlatas." (SÃO PAULO, 2016, s/p). Com base no regulamento, o professor interlocutor de Libras deve atuar nas unidades escolares da rede estadual de ensino que apresentarem alunos surdos ou com deficiência auditiva, regularmente matriculados no Ensino Fundamental e no Ensino Médio, inclusive na Educação de Jovens e Adultos (EJA).

Conforme a "Instrução da CGEB", compete ao "professor interlocutor de Libras":

8.2.1 - fazer a interpretação para os alunos surdos/deficientes auditivos em grupos de até 4 (quatro), por sala;

8.2.2- conhecer antecipadamente o conteúdo das aulas;

8.2.3- organizar antecipadamente as palavras e os apoios visuais;

8.2.4- apresentar todo o conteúdo em Libras, com o apoio de recursos visuais e/ou tecnológicos;

8.2.5- posicionar-se em frente ao(s) aluno(s) com surdez/deficiência auditiva e interpretar conforme comunicação, por eles adquirida;

8.2.6- transmitir ao professor as dúvidas dos alunos com surdez/deficiência auditiva, garantindo, assim, a mediação entre eles;

8.2.7- interpretar, também, a interação dos colegas com o professor e outros eventos em que a unidade escolar participe;

8.2.8- interpretar a avaliação em Libras, zelando pela coerência entre os conceitos e o objetivo estabelecido;

8.2.9- realizar adaptações de acesso ao currículo, antecipadamente, juntamente com o professor da classe/aula comum, bem como trabalhar na complementação dos conceitos;

8.2.10- solicitar ao professor da classe/aula comum a explicação do conceito por ele apresentado e não entendido pelo aluno, sempre que este precisar. (SÃO PAULO, 2015, s/p)

A propósito do disposto, Martins (2006) assevera que quando uma proposta inclusiva transfere toda a tarefa da inclusão do surdo para tradutor e intérprete de Libras, como se ele sozinho conseguisse reverter a problemática educacional, mas o currículo e a metodologia permanecem inalterados, tanto o estudante surdo quanto seu intérprete se veem "apagados" da cena educacional, o que, evidentemente, opera uma dupla exclusão.

Quanto à formação do "professor interlocutor de Libras", o artigo $3^{\circ}$ da Resolução SE n 8/2016 dispõe sobre a necessidade de o profissional ser portador de, pelo menos, um dos seguintes diplomas: I - licenciatura plena em Pedagogia ou em curso Normal Superior; II - licenciatura plena; III - diploma de nível médio com habilitação em magistério ou; IV - diploma de bacharel ou tecnólogo de nível superior. É também necessário comprovar a aptidão para o desempenho da função, por meio de um dos seguintes títulos: 
http://dx.doi.org/10.5902/1984686X38356

1 - diploma ou certificado de curso de licenciatura em "Letras - LIBRAS";

2 - certificado expedido por instituição de ensino superior ou por instituição credenciada por Secretarias Estaduais ou Municipais de Educação;

3 - certificado de habilitação ou especialização em Deficiência Auditiva/Audiocomunicação com horária mínima de 120 (cento e vinte) horas em LIBRAS;

4 - diploma de curso de licenciatura acompanhado de certificado de proficiência em LIBRAS, com carga horária mínima de 120 (cento e vinte) horas;

5 - diploma de curso de licenciatura, com mínimo de 120 (cento e vinte) horas de LIBRAS no histórico do curso; [...] (SÃO PAULO, 2016, s/p).

Ao comungar dos constructos de Lacerda (2012), reconhecemos que, no espaço educacional, o tradutor e intérprete de Libras não é um instrumento de apoio ao ensino ou somente aquele que cumpre a tarefa de versar de uma língua para outra, nas relações interpessoais. Logo, suspeitamos, sobretudo, do tipo de formação admitida para o cargo de professor interlocutor de Libras na rede estadual paulista, porque o parâmetro de 120 horas de formação corresponde a um curso de nível básico e, portanto, insuficiente para garantir a fluência na língua de sinais. Em vista disso, avaliamos que a contratação de um profissional com esse nível de formação certamente incide em prejuízos linguísticos e acadêmicos para o estudante surdo, desqualificando seu processo educacional.

Ao reconhecermos a importância das prerrogativas do Decreto Federal $\mathrm{n}^{0}$ 5.626/2005, quando preconiza que o cargo/função de professor e/ou instrutor de Libras seja destinado prioritariamente aos profissionais surdos, "[...] visto que eles são modelo linguístico e de identidade surda, fomentam o uso da Libras em todos os espaços da escola e [...] têm condições experienciais e linguísticas de contribuir de forma ímpar para a construção de uma didática bilíngue" (LACERDA; ALBRES; DRAGO, 2013, p. 75). Destacamos a opção pela indicação do cargo de professor de Libras prioritariamente surdo, situada na estratégia 4.13 do PNE-2014 e, reciprocamente, em 15 dos 27 Planos de Educação examinados: PEE-AL, PEE-AP, PEE-AM, PDE-DF, PEE-ES, PEE-MS, PEEMG, PEE-PA, PEE-PB, PEE-PR, PEE-PI, PEE-RS, PEE-RO, PEE-SE e PEE-TO, bem como a indicação do cargo de instrutor de Libras surdo, presente na estratégia 4.11 do PEE-AC.

Em contrapartida, relativizamos a escolha expressa em 8 PEEs - PEE-AC, PEE-BA, PEE-PE, PEE-RN, PEE-SC (professor de Libras) e PEE-GO, PEE-MA, PEE-RO (instrutor de Libras) - pois, ao suprimir o requisito de prioridade reservado aos surdos para ocupação dos cargos de professor e/ou instrutor de Libras, favorece a contratação de 
professores e/ou instrutores de Libras ouvintes, implicando prejuízos para a construção da subjetividade daqueles que na escola se encontram, ao privá-los da oportunidade de ter uma percepção positiva da surdez. Por outro lado, tal escolha remete à dificuldade imposta pela necessidade de suprir a demanda de contratação e a disponibilidade de profissionais com o nível de formação exigido para a atuação no cargo/função.

No que diz respeito às denominações professor e instrutor de Libras, essa diferença está relacionada com o grau de titulação, sendo que o profissional é intitulado professor de Libras, por ser graduado, ou instrutor de Libras, por ter formação em nível médio.

No que concerne à atuação, de acordo com o Decreto Federal ํo 5.626/2005, o professor de Libras está apto para atuar nos anos finais do Ensino Fundamental, no Ensino Médio e na Educação Superior, sendo admitida a atuação do instrutor apenas na Educação Infantil e nos anos iniciais do Ensino Fundamental, desde que este tenha cursado o Ensino Médio na modalidade normal, "[...] em que Libras e Língua Portuguesa escrita tenham constituído línguas de instrução, viabilizando a formação bilíngue" (BRASIL, 2005, s/p). Situação essa que revela a discrepância do discurso oficial em relação à exigência formativa para atuar em diferentes níveis de ensino, podendo comprometer uma etapa tão importante, no que se refere à aquisição da língua e ao desenvolvimento linguístico.

Quanto à indicação de professor bilíngue, verificada na estratégia 4.13 do PNE-2014 e também em 17 dos 27 Planos de Educação investigados, pode-se afirmar que tal opção condiz com a determinação do Decreto Federal no 5.626/2005, posto que, ao definir a organização da oferta da educação bilíngue, o Artigo 22 do referido documento prevê a atuação dos professores bilíngues, nas escolas e classes bilíngues, na Educação Infantil e nos anos iniciais do Ensino Fundamental.

Ao discorrerem sobre a formação desse profissional, Lacerda, Albres e Drago (2013, p. 71) ressaltam que "[...] o conceito de professor bilíngue é ainda fluido, sem contornos bem definidos", porque, embora o artigo $5^{\circ}$ do Decreto Federal № 5.626/2005 institua sua formação em curso de pedagogia bilíngue,

[...] não menciona detalhes da formação para a execução de uma educação bilíngue, ou seja, não faz referência a aspectos da formação pedagógica para a prática de ensino no contexto da educação bilíngue. O fato de a formação se dar em duas línguas distintas de instrução não garante a apropriação de saberes docentes para a execução de uma educação bilíngue. (LACERDA; ALBRES; DRAGO, 2013, p. 71). 
Em outras palavras, o perfil do professor bilíngue vai além de seu domínio linguístico em Português, de seu domínio linguístico em Libras ou de sua formação como professor. Exige também o conhecimento de processos de ensino-aprendizagem, procedimentos metodológicos e curriculares que levem em conta as diferenças socioculturais e linguísticas coexistentes na escola.

Nesse caso, o fomento da criação de cursos de pedagogia bilíngue, indicado nas estratégias 4.26 do PEE-MA, 12.12 do PEE-MS e 17.7 do PEE-TO (Figura 2) deve ser compreendido como uma medida positiva. Avaliamos ainda que o processo de consolidação dessas estratégias mereça ser investigado, no sentido de evidenciar contribuições quanto à apropriação dos saberes docentes, tão necessários para a concretização da oferta de uma proposta educacional bilíngue (Libras e Língua Portuguesa).

No que tange ao provimento do cargo/função de "professores de Libras e do ensino de Língua Portuguesa na modalidade escrita, como segunda língua", citados nas estratégias 4.11 do PEE-AC e 4.3 do PEE-RN, é possível reconhecer a observância aos termos do artigo 14 do Decreto Federal no 5.626/2005, o qual recomenda o provimento do cargo de "professor para o ensino de Língua Portuguesa como segunda língua para pessoas surdas" (BRASIL, 2005, s/p), além de supor que há uma compreensão distinta acerca das atribuições desse profissional em relação ao professor do $A E E$, uma vez que os dois cargos/funções são especificados no mesmo enunciado.

Recorrendo aos constructos teóricos de Lacerda, Albres e Drago (2013), é possível presumir que, ao sugerir a inserção do cargo/função de "professor de Libras e do ensino de Língua Portuguesa na modalidade escrita, como segunda língua", os PEE do Acre e do Rio Grande do Norte façam referência tanto aos professores bilíngues com formação em pedagogia que trabalham com o letramento nas séries iniciais, quanto àqueles com formação em Letras/Português (especialistas) que ministram a disciplina de Língua Portuguesa, os quais têm o desafio de desenvolver ações pedagógicas compatíveis com o ensino do português na modalidade escrita, com base nos conhecimentos em língua de sinais.

No caso do PEE-CE e do PPE-RJ, a supressão dos cargos/funções de professor e/ou instrutor de Libras (prioritariamente surdo), tradutor e intérprete de Libras, professor bilíngue e, até mesmo, professor do AEE, no processo de recontextualização da 
http://dx.doi.org/10.5902/1984686X38356

estratégia 4.13 do PNE-2014, para elaboração de suas respectivas estratégias (PEE-CE 4.9 e PEE-RJ 4.18), leva-nos a supor a resistência dos sistemas estaduais de ensino do Ceará e Rio de Janeiro quanto à viabilização da oferta da educação bilíngue para os estudantes, especialmente surdos, matriculados nas instituições estaduais, uma vez que a indicação de "acompanhante especializado" ou de "mediador pedagógico (professor)" é incompatível com as recomendações do Decreto Federal no 5.626/2005 e, portanto, com a possibilidade de ofertar alternativas educacionais as quais garantam os direitos linguísticos e a formação bilíngue dos estudantes matriculados nos respectivos sistemas de ensino.

\section{Considerações}

Em suma, os desafios ligados à composição de uma equipe profissional condizente com a consolidação de uma proposta educacional bilíngue (Libras e Língua Portuguesa), atenta à construção de uma percepção positiva da surdez por todos os que na escola circulam, estão diretamente ligados ao equacionamento da oferta de cursos de graduação e pós-graduação que assegurem a formação de professores surdos e ouvintes para a docência da e em Libras, à necessidade de reconhecimento da relevância da presença de instrutores e/ou professores surdos nas escolas, à regulamentação do cargo/função de intérprete educacional para atuar nas instituições de ensino, à urgência em se conseguir professores bilíngues com proficiência na Libras e na Língua Portuguesa, mas também com uma formação que abranja conhecimentos didáticos e de currículo, entre outras questões, as quais impactam diretamente os sistemas federais, estaduais, distrital e municipais de ensino.

Nesse ínterim, embora este estudo revele importantes proposições do PNE-2014 e dos PEE e PDE investigados, no sentido de garantir a presença de profissionais habilitados a atender as demandas educacionais e linguísticas dos estudantes surdos e fomentar a existência do bilinguismo, na escola, prevalecem providências intimamente relacionadas com as orientações expressas no documento da "Política Nacional da Educação Especial na perspectiva da Educação Inclusiva" (BRASIL, 2008), no qual o conceito estreito e simplista de bilinguismo reduz essa proposta de educação à tradução da língua de sinais pela língua oral. Ademais, a Libras é rebaixada à condição de recurso para o ensino em português, permitindo supor que a matrícula do estudante surdo na sala 
http://dx.doi.org/10.5902/1984686X38356

comum do ensino regular, sob acompanhamento de tradutor e intérprete de Libras, paralelamente ao ensino da Libras e da Língua Portuguesa como segunda língua, na modalidade escrita, ofertadas como atividades de complementação curricular, consolidam uma proposta educacional inclusiva bilíngue.

Assim, desatendo-nos às diferentes denominações e perfis, verificamos 25 indicações de profissionais com atribuições associadas à interpretação da Libras-Língua Portuguesa e 22 indicações de profissionais destinados ao AEE, no contraturno da escolarização, em detrimento das 20 indicações de professores de Libras, sendo $15 \mathrm{com}$ prioridade de vagas para candidatos surdos, 4 indicações de instrutores de Libras, ficando somente uma com prioridade reservada a candidatos surdos e 17 indicações de professores bilíngues, responsáveis por atuar nas escolas e classes bilíngues na Educação Infantil e no Ensino Fundamental.

Sob tais ponderações, considerando que o PNE-2014 e os Planos Estaduais e Distrital de Educação têm vigência de um decênio, vemos a fragilidade no cumprimento do Decreto Federal oㅗ 5.626/2005, por praticamente duas décadas, a contar de sua publicação, e, consequentemente, o distanciamento de alguns dos sistemas estaduais de ensino com o projeto de consolidação de uma proposta educacional atenta à condição bilíngue implicada na surdez e as prerrogativas de uma política educacional que faça jus aos direitos linguísticos de estudantes surdos e ouvintes, em espaços educacionais bilíngues, os quais promovam ações capazes de equalizar o status das línguas em circulação nessa escola e avançar nas reflexões que aprisionam a compreensão da oferta da Libras como recurso, um acessório para viabilizar o ensino em português.

$\mathrm{Na}$ verdade, a noção de direito linguístico vem sendo afetada pelo campo de orientação da política linguística que compreende a Língua como Recurso, indicando que não basta falar ou escrever a língua oficial, mas também levar em conta a proeminência do multiletramento no campo digital de produção do conhecimento em diferentes línguas, sem perder de vista que a exaltação do mercado das línguas - softwares, aplicativos de celular, preparação das línguas com uma multiplicidade de bancos de dados - não pode suplantar o fato de que as línguas são constituídas pelas experiências humanas, ao mesmo tempo que constituem o humano na relação dialógica, da qual o ensino em Libras não pode ser suprimido. 
http://dx.doi.org/10.5902/1984686X38356

Assim, a presença de professores e instrutores surdos e professores bilíngues é imprescindível para a constituição positiva da surdez e valorização da Libras, uma vez que estes viabilizam a circulação da língua de sinais em todos os espaços da escola e têm vivências linguísticas e culturais necessárias para a construção de uma didática bilíngue, que permita aos estudantes se reconhecerem como sujeitos bilíngues, plurilíngues e multiculturais.

\section{Referências}

BALL, Stephen John. Diretrizes políticas globais e relações políticas locais em educação. Currículo sem fronteiras. v. 1, n. 2, p. 99-116, jul./dez. 2001.

BRASIL. Constituição da República Federativa do Brasil. Promulgada em 5 de outubro de 1988. Diário Oficial da União. Brasília, DF, Senado, 191-A, 5 out. 1988. Disponível em: http://www.planalto.gov.br/ccivil_03/constituicao/ConstituicaoCompilado.htm. Acesso em: 19 jan. 2016.

BRASIL. Lei no 9.394, de 20 de dezembro de 1996. Lei que estabelece as Diretrizes e Bases da Educação Nacional. Diário Oficial da União. Brasília, DF, 23 dez. 1996. Disponível em: http://www.planalto.gov.br/ccivil_03/leis/L9394.htm. Acesso em: 18 ago. 2016.

BRASIL. Decreto no 5.626, de 22 de dezembro de 2005. Regulamenta a Lei $n^{\circ} 10.436$, de 24 de abril de 2002, que dispõe sobre a Língua Brasileira de Sinais - Libras e, o art. 18 da Lei $n^{\circ}$ 10.098, de 19 de dezembro de 2000. Diário Oficial da União. Brasília, DF, 2005. Disponível em:

http://www.planalto.gov.br/ccivil_03_ato20042006/2005/decreto/d5626.htm. Acesso em: 15 abr. 2015.

\section{BRASIL. Documento da Política Nacional de Educação Especial na Perspectiva da} Educação Inclusiva. Brasília: MEC/SEESP, 2008. Disponível em: http://portal.mec.gov.br/index.php?option=com_docman\&view=download\&alias=16690politica-nacional-de-educacao-especial-na-perspectiva-da-educacaoinclusiva05122014\&Itemid=30192. Acesso em: 18 ago. 2015.

BRASIL. Decreto no 6.949, de 25 de agosto de 2009. Promulga a Convenção Internacional sobre os Direitos das Pessoas com Deficiência e seu Protocolo Facultativo, assinados em Nova York, em 30 de março de 2007. Diário Oficial da União. Brasília, DF. 26 ago. 2009a. Disponível em:

http://www.planalto.gov.br/ccivil_03/_ato20072010/2009/decreto/d6949.htm. Acesso em: 18 ago. 2016. 
http://dx.doi.org/10.5902/1984686X38356

BRASIL. Resolução n.o 04, de 02 de outubro de 2009. Institui Diretrizes Operacionais para o Atendimento Educacional Especializado na Educação Básica, modalidade Educação Especial. Brasília, DF. 2009b. Disponível em:

http://portal.mec.gov.br/dmdocuments/rceb004_09.pdf. Acesso em: 20 jan. 2015.

BRASIL. Tradutor e Intérprete da Língua Brasileira de Sinais - LIBRAS. Diário Oficial da União. Brasília, DF, 02 set. 2010. Disponível em: http://www.planalto.gov.br/ccivil_03/_ato2007-2010/2010/lei/l12319.htm. Acesso em: 13 jan. 2018.

BRASIL. Decreto oㅜ 7.611, de 17 de novembro de 2011. Dispõe sobre a educação especial, o atendimento educacional especializado e dá outras providências. Diário Oficial da União. Brasília, DF, 18 nov. 2011. Disponível em: http://www.planalto.gov.br/ccivil_03/_ato2011-2014/2011/decreto/d7611.htm. Acesso em: 24 jan. 2017.

BRASIL. Lei no 13.005, de 25 de junho de 2014. Lei que dispõe sobre o Plano Nacional de Educação - PNE e dá outras providências. Diário Oficial da União. Brasília, DF. 26 jun. 2014b. Disponível em:

http://www.planalto.gov.br/ccivil_03/_ato20112014/2014/lei//13005.htm. Acesso em: 18 ago. 2016.

BRASIL. Lei o 13.146, de 6 de julho de 2015. Institui a Lei Brasileira de Inclusão da Pessoa com Deficiência (Estatuto da Pessoa com Deficiência). Diário Oficial da União. Poder Executivo, Brasília, DF, 7 jul. 2015. Disponível em: http://www.planalto.gov.br/ccivil_03/_ato2015-2018/2015/lei//13146.htm. Acesso em: 18 ago. 2016.

BRASIL. Caderno de Instruções: Censo Escolar da Educação Básica 2017. Brasília: MEC/INEP/DEED/CGCEB, 2017. Disponível em:

http://download.inep.gov.br/educacao_basica/censo_escolar/caderno_de_instrucoes/cade rno_de_instrucoes_censo_escolar_2017.pdf. Acesso em: 27 jun. 2017.

FERNANDES, Sueli; MOREIRA, Laura Ceretta. Políticas de educação bilíngue para surdos: o contexto brasileiro. Educar em Revista, Curitiba: UFPR, Edição Especial n. 2, p. 51-69, 2014. Disponível em: http://ojs.c3sl.ufpr.br/ojs/index.php/educar/article/view/37014. Acesso em: 29 jun. 2015.

FORQUIN, Jean-Claude. Escola e Cultura: as bases sociais e epistemológicas do conhecimento escolar. Porto Alegre: Artes Médicas, 1993.

GUEDES, Betina Silva. Sobre surdos, bocas e mãos: saberes que constituem o currículo de fonoaudiologia. 150 f. Dissertação (Mestrado em Educação) - Universidade do Vale do Rio dos Sinos (UNISINOS), São Leopoldo, 2010. 
http://dx.doi.org/10.5902/1984686X38356

KUMADA, Kate Mamhy Oliveira. O. Acesso do surdo a cursos superiores de formação de professores de Libras em instituições federais. 2017. 245 f. Tese (Doutorado em Educação) - Universidade de São Paulo (USP), Faculdade de Educação, São Paulo, 2017.

LACERDA, Cristina Broglia Feitosa de. O intérprete de Língua Brasileira de Sinais (ILS). In: LODI, Ana Cláudia Balieiro; MÉLO, Ana Dorziat Barbosa de; FERNADES, Eulalia (Org.). Letramento, bilinguismo e educação de surdos. Porto Alegre: Mediação, 2012. p. 247287.

LACERDA, Cristina Broglia Feitosa de; ALBRES, Neiva Albres; DRAGO, Silvana Lucena dos Santos. Política para uma educação bilíngue e inclusiva a alunos surdos no município de São Paulo. In: Educação e Pesquisa, São Paulo, v. 39, n. 1, jan./mar. 2013, p. 65-80.

LODI, Ana Cláudia Balieiro. Plurilinguismo e surdez: uma leitura bakhtiniana da história da educação dos surdos. Educação e Pesquisa, São Paulo, v. 31, n. 3, p. 409-424, set./dez. 2005.

LODI, Ana Cláudia Balieiro; ALBUQUERQUE, Graziele Kathleen Tavares Santana de. Sala Libras língua de instrução: inclusão ou exclusão educacional/social? In: LACERDA, Cristina Broglia Feitosa de; SANTOS, Lara Ferreira dos; MARTINS, Vanessa Regina de Oliveira (Org.). Escola e diferença: caminhos da educação bilíngue para surdos. São Carlos: EDUFScar, 2016.

MARTINS, Vanessa Regina de Oliveira. O que me torna invisível?: a psicanálise como ferramenta para entender o "apagamento" das diferenças na inclusão escolar de surdos. ETD: Educação Temática Digital, Campinas, v. 8, n. esp., p. 134-150, 2006. (150 anos de Freud). Disponível em:

http://143.106.58.55/revista/viewarticle.php?id=322\&layout=abstract. Acesso em: 20 dez. 2015.

NASCIMENTO, Sandra Patrícia de Faria do; COSTA, Messias Ramos. Movimentos surdos e os fundamentos e metas da escola bilíngue de surdos: contribuições ao debate institucional. Educar em Revista, Curitiba: Editora UFPR, Edição Especial n. 2, p. 159178, 2014.

NUNES, Jozanes Assunção. Vozes em confronto no Núcleo Docente Estruturante de cursos de Letras: entre o prescrito e a prática institucionalizada. Bakhtiniana, São Paulo, v. 13, n. 2, p. 117-138, maio/ago. 2018.

OLIVEIRA, Gilvan Müller de. Políticas linguísticas como políticas públicas. In: BERTUSSI, Teresinha; OURIQUES, Nildo (Org.). Anuário Educativo Brasileiro: Visão Retrospectiva. São Paulo: Cortez, 2011, p. 313-333. 
http://dx.doi.org/10.5902/1984686X38356

OLIVEIRA, Gilvan Müller de. Políticas Linguísticas: uma entrevista com Gilvan Müller de Oliveira. ReVEL, v. 14, n. 26, p. 382-399, 2016.

PAGURA, Reynaldo José. A interpretação de conferências: interfaces com a tradução escrita e implicações para a formação de intérpretes e tradutores. D.E.L.T.A, 19: Especial, p. 209-236, 2003.

QUADROS, Ronice Muller de. O tradutor e intérprete de Língua Brasileira de Sinais e Língua Portuguesa. Secretaria de Educação Especial; Programa Nacional de Apoio à Educação de Surdos. Brasília: MEC/SEESP, 2004.

RÓNAI, Paulo. Escola de tradutores. 5. ed. Rio de Janeiro: Nova Fronteira, 1987.

RUÍZ, Richard. Orientations in language planning. NABE: The Journal for the National Association for Bilingual Education, v. 8, n. 2, p. 15-34, 1984.

SÃO PAULO (Estado). Instrução CGEB, de 14 de janeiro de 2015. Dispõe sobre a escolarização de alunos com surdez/deficiência auditiva (DA) da Rede Estadual de Ensino de que trata a Resolução SE no 61/2014. São Paulo: CGEB, 2015.

SÃO PAULO (Estado). Resolução SE 8, de 29 de janeiro de 2016. Dispõe sobre a atuação de docentes com habilitação/ qualificação na Língua Brasileira de Sinais LIBRAS, nas escolas da rede estadual de ensino, e dá providências correlatas. São Paulo: Secretaria da Educação, 2016.

SÃO PAULO (Estado). Resolução SE 68, de 12 de dezembro de 2017. Dispõe sobre o atendimento educacional aos alunos, público-alvo da Educação Especial, na rede estadual de ensino. São Paulo: Secretaria da Educação, 2017.

SILVA, Rubia Carla Donda da. Educação de surdos nos Planos Estaduais e Distrital de Educação. 2018. 255 f. Dissertação (Mestrado em Educação) - Universidade Estadual Paulista (UNESP), Faculdade de Filosofia e Ciências, Marília, 2018.

SILVEIRA, Brenno. A arte de traduzir. 2. ed. São Paulo: UNESP; Melhoramentos, 2004.

THEODOR, Erwin. Tradução: ofício e arte. $3^{\mathrm{a}}$ ed. São Paulo: Cultrix, 1976.

THOMA, Adriana da Silva. Representações sobre os surdos, comunidades, cultura e movimento surdo. In: LOPES, M. C. (Org.). Cultura surda \& Libras. São Leopoldo, RS: Editora da UNISINOS, 2012. p. 154-180.

VOLOCHÍNOV, Valentim Nikolaevich; BAKHTIN, Mikhail Mikhailovich. Marxismo e filosofia da linguagem: problemas fundamentais do método sociológico da linguagem. São Paulo: Hucitec, 2014. 
http://dx.doi.org/10.5902/1984686X38356

\section{Correspondência}

Rubia Carla Donda da Silva - Universidade Estadual Paulista Júlio de Mesquita Filho, Faculdade de Filosofia e Ciências - Campus de Marília, Rua Hygino Muzzi Filho, n. 737, Marília, São Paulo - Brasil. CEP: 17525-900.

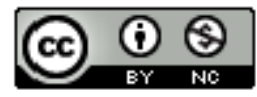

This work is licensed under a Creative Commons Attribution-NonCommercial 4.0 International (CC BY-NC 4.0) 